\title{
Maintenance therapy: a two year comparison between Caved-S and cimetidine treatment in the prevention of symptomatic gastric ulcer recurrence
}

\author{
A G MORGAN, C PACSOO, AND W A F McADAM \\ From the Endoscopy Unit, Airedale General Hospital, Steeton, Keighley, West Yorkshire
}

SUMMARY Eighty two patients with an endoscopically healed gastric ulcer, were treated for two years with either Caved-S tablets, two twice daily or cimetidine $400 \mathrm{mg}$ at night. During the first year, $12 \%$ (four out of 34) of the Caved-S group and 10\% (four out of 41 ) of the cimetidine group had an ulcer recurrence. By the end of the second year, the recurrence rate was $29 \%$ (nine out of 31) in the Caved-S group, and 25\% (eight out of 32) for the cimetidine group. Ulcer relapse occurred frequently in patients with either a dyspeptic history of over six months $(\mathrm{p}<0 \cdot 05)$, or a past history of a gastric ulcer $(\mathrm{p}<0.001)$. Ulcers recurred rapidly after maintenance therapy; Caved-S two out of 22; cimetidine seven out of 23, within four months (NS). This study shows that long term maintenance therapy is safe and reasonably effective. The high recurrence rate after stopping treatment suggests that therapy in high risk or elderly patients should be for life.

In 1982 we published the results of a comparison between cimetidine and Caved-S in the treatment of gastric ulceration, with the preliminary results of the subsequent two year period of maintenance therapy. ${ }^{1}$ In this paper we present the final results of that study, and also review the place of such treatment in the prevention of gastric ulcer recurrence.

\section{Methods}

PATIENTS

Eighty two patients with healed gastric ulcers were treated for two years with either Caved-S (deglycyrrhizinated liquorice, antacids, and up to 1980 bismuth subcitrate) two tablets twice daily or cimetidine $400 \mathrm{mg}$ at night. They were seen as outpatients at three monthly intervals. All patients with a return of symptoms lasting for more than a few days were endoscoped. After six months treatment, a barium meal was carried out. Standard haematological and biochemical screening was undertaken at six monthly intervals. All patients who completed the study were then followed up for a further four months.

Address for correspondence: Dr A G Morgan, Airedale General Hospital, Skipton Road, Steeton, Keighley, W Yorks BD20 6TD.

Received for publication 13 July 1984.
STATISTICAL METHODS

The Log-rank test as described by Peto et $a l^{2}$ was used to compare ulcer recurrence in the two groups, and to look for factors influencing it.

\section{Results}

The two treatment groups were evenly matched for all important parameters (Table 1). The recurrence rate in the two groups was similar (NS see Table 2). During the two years treatment, approximately a quarter of the patients relapsed.

The withdrawal rate for the two year treatment periods were similar (Table 3). One patient with an antral ulcer healed on Caved-S, developed a gastric cancer high on the lesser curve 16 months later. The safety screening programme picked up one patient on cimetidine who developed abnormal liver function tests (SGPT 109) but these returned to normal within two months of stopping treatment.

Within four months of stopping maintenance therapy, nine ulcers recurred, seven in patients who had been on cimetidine, and two in those on Caved-S (NS see Table 2).

The duration of ulcer disease, and a past history of gastric ulcer predispose to ulcer recurrence ( $p<0.05$ and $p<0.001$ respectively). Recurrence is not influenced by initial treatment, sex, age, smok- 
Table 1 Comparability of treatment groups

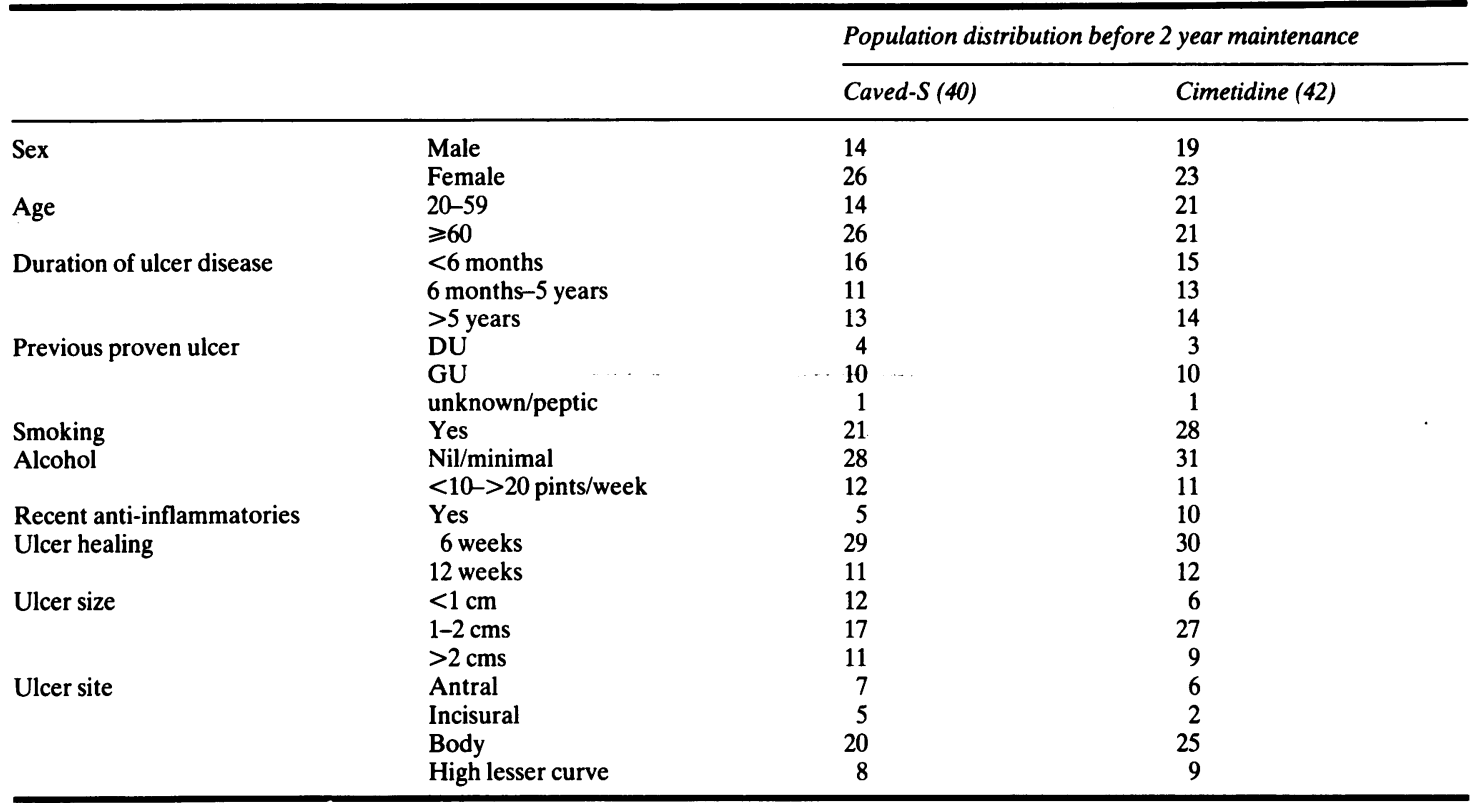

ing, or drinking habits, ulcer size or site, inpatient treatment at the start of therapy or non-steroidal anti-inflammatory drug therapy.

\section{Discussion}

Modern treatment methods will heal the majority of gastric ulcers in two to three months, but ulcer recurrence is known to be rapid once therapy is stopped (30-90\% within a year). ${ }^{3-10}$ Unlike duodenal ulcers, gastric ulcers occur mainly in the el-

Table 2 Results of two years maintenance treatment and subsequent four month follow up

\begin{tabular}{lll}
\hline & Caved-S & Cimetidine \\
\hline Year one & & \\
Started Year 1 & 40 & 42 \\
Withdrawn & 6 & 1 \\
$\quad$ Ulcer recurrences & $4(12 \%)$ & $4(10 \%)$ \\
Year two & & \\
$\quad$ Started year 2 & 30 & 37 \\
$\quad$ Withdrawn & 3 & 9 \\
$\quad$ Ulcer recurrences & $5(19 \%)$ & $4(14 \%)$ \\
Combined results for year 1 and 2 & & \\
$\quad$ Withdrawn & 9 & 10 \\
$\quad$ Ulcer recurrences & $9(29 \%)$ & $8(25 \%)$ \\
Four month follow up after treatment & & \\
$\quad$ Started & 22 & 24 \\
$\quad$ Withdrawn & 0 & $7(30 \%)$ \\
$\quad$ Ulcer recurrences & $2(9 \%)$ & \\
\hline
\end{tabular}

derly. About $20 \%$ may be related to non-steroidal anti-inflammatory drug therapy, and many patients have multiple pathology. Almost a quarter present with either haematemasis or melaena, and in the elderly this carries a high mortality. It is because of such risk factors that a safe and effective maintenance therapy has so much to offer.

Our two treatment regimes were equally effective. During the first year $12 \%$ of the Caved-S group, and $10 \%$ of the cimetidine group had an ulcer recurrence. After two years treatment this

Table 3 Reasons for withdrawal

\begin{tabular}{|c|c|c|}
\hline & \multicolumn{2}{|l|}{ Treatment group } \\
\hline & Caved-S & Cimetidine \\
\hline Year one & $\begin{array}{l}2 \text { died } \\
1 \text { severe oesophagitis } \\
2 \text { too frail to attend } \\
1 \text { lost to follow up }\end{array}$ & 1 died \\
\hline Year two & $\begin{array}{l}1 \text { surgery for gastric } \\
\text { cancer } \\
1 \text { too frail to attend } \\
1 \text { lost to follow up }\end{array}$ & $\begin{array}{l}3 \text { died } \\
1 \text { surgery for leiomyoma } \\
1 \text { raised SGPT (109) } \\
2 \text { lost to follow up } \\
1 \text { stopped treatment } \\
1 \text { recurrence of symptoms } \\
\text { (not endoscoped) }\end{array}$ \\
\hline
\end{tabular}


had risen to $29 \%$ and $25 \%$ respectively. In a previous study we followed a similar group of unselected patients, not on maintenance therapy, for two years and found a recurrence rate of $33 \%$ after one year, rising to $44 \%$ at the end of two years.

A review of the literature ${ }^{3-10}$ shows a one year recurrence rate on maintenance therapy of $0-21 \%$ but few studies have continued beyond this (Table 4).

The incidence of asymptomatic ulcer recurrence is unclear. Hentschel and coworkers ${ }^{6}$ found that $24 \%$ of the relapses in their study were asymptomatic. In a recent review of maintenance therapy with ranitidine ${ }^{11}$ only $7 \%$ of the ulcer recurrences were asymptomatic. We looked for asymptomatic ulcer recurrence by radiology after six months treatment and found two ulcers. The importance of an ulcer recurrence that produces neither symptoms nor complications is unknown.

This study confirms that two years of maintenance therapy with either Caved-S or cimetidine will reduce symptomatic ulcer recurrence safely and effectively. Patients with a past history of gastric ulceration and dyspeptic symptoms of more than six months duration are more likely to have a recurrence during therapy $(\mathrm{p}<0.05$ and $\mathrm{p}<0.001$ respectively). These patients may require full healing dosage for maintenance therapy to keep them in remission.

How long should maintenance therapy be continued? In an attempt to answer this question, the patients were followed for a further four months after maintenance therapy was stopped. Twenty per cent of these patients developed an ulcer recur- rence within this observation period, two out of 22 $(9 \%)$ in the Caved-S group and seven out of 23 $(30 \%)$ in the cimetidine group (NS). This rapid gastric ulcer recurrence after stopping maintenance therapy has not been recorded previously although it is well recognised in duodenal ulcer disease. ${ }^{12}{ }^{13}$

During the four month period, one of the patients (who had previously been on cimetidine), presented with a severe gastrointestinal bleed from a large recurrent ulcer, and died after surgery. Maintenance therapy should perhaps be for life in the elderly or those with multiple pathology, particularly as the standard operation for gastric ulcer is a Bilroth I partial gastrectomy, with its associated mortality and morbidity.

The authors would like to thank their colleagues for their help with his study, and to Mr David Underwood of Smith, Kline and French Laboratories for undertaking the statistical analyses.

\section{References}

1 Morgan AG, McAdam WAF, Pacsoo C, Darnborough $\mathrm{A}$. Comparison between cimetidine and Caved-S in the treatment of gastric ulceration, and subsequent maintenance therapy. Gut 1982; 23: 545-51.

2 Peto R. et al. Design and analysis of randomized clinical trials requiring prolonged observation of each patient. Part II. Br J Cancer 1977; 35: 1-39.

3 La Brooy SJ, Taylor RH, Ayrton C, et al. Cimetidine

Table 4 Review of maintenance studies in gastric ulcer disease

\begin{tabular}{|c|c|c|c|c|c|c|c|c|c|c|c|}
\hline \multirow[b]{3}{*}{ Author } & \multirow{3}{*}{$\begin{array}{l}\text { Drug and } \\
\text { dosage }\end{array}$} & \multirow{3}{*}{$\begin{array}{l}\text { Patients } \\
\text { (no) }\end{array}$} & \multirow{2}{*}{\multicolumn{3}{|c|}{$\frac{\% \text { Recurrence }}{\text { Follow up }(m)}$}} & \multirow{3}{*}{$\begin{array}{l}\text { Drug and } \\
\text { Dosage }\end{array}$} & \multirow{3}{*}{$\begin{array}{l}\text { Patients } \\
\text { (no) }\end{array}$} & \multirow{2}{*}{\multicolumn{3}{|c|}{$\frac{\% \text { Recurrence }}{\text { Follow up (m) }}$}} & \\
\hline & & & & & & & & & & & \\
\hline & & & $6-7$ & $11-12$ & 24 & & & $6-7$ & $11-12$ & 24 & \\
\hline & Cimetidine & & & & & Placebo & & & & & \\
\hline $\begin{array}{c}\text { La Brooy, Taylor, } \\
\text { Ayrton, } \text { et al }^{3}\end{array}$ & $200 \mathrm{mg}$ qid & 15 & 13 & - & - & & 14 & 21 & - & - & NS \\
\hline $\begin{array}{l}\text { Machell, Ciclitira, } \\
\text { Farthing, et } \text { l }^{4}\end{array}$ & $\begin{array}{l}200 \mathrm{mg} \text { tds } \\
400 \text { nocte }\end{array}$ & 11 & - & 18 & - & & 14 & - & 86 & - & $<0.002$ \\
\hline $\begin{array}{l}\text { Birger Jensen, Møllmann, } \\
\text { Rahbek, et al }\end{array}$ & $400 \mathrm{mg}$ bd & 10 & - & 0 & - & & 9 & - & 55 & - & $<0.025$ \\
\hline $\begin{array}{l}\text { Hentschel, Schütze, } \\
\text { Weiss, et al }\end{array}$ & $400 \mathrm{mg}$ nocte & 42 & - & 14 & - & & 42 & - & 55 & - & $<0.001$ \\
\hline Barr, Kang, & $400 \mathrm{mg}$ bd & 24 & - & 21 & - & & 25 & - & 48 & - & $0.02<\mathrm{p}<0.05$ \\
\hline Canalese, et al ${ }^{7}$ & Ranitidine & & - & - & 33 & & - & - & - & 52 & NS \\
\hline Cockel, Dawson, Jain ${ }^{8}$ & $\begin{array}{l}\text { Ranitidine } \\
150 \text { mg nocte }\end{array}$ & 19 & 6 & - & - & & 20 & 42 & - & - & $<0.05$ \\
\hline $\begin{array}{l}\text { Hellier, Gent, } \\
\text { Walker, et al }{ }^{9}\end{array}$ & $\begin{array}{l}150 / 100 \mathrm{mg} \\
\text { nocte }\end{array}$ & 32 & 6 & - & - & & 12 & 33 & - & - & $<0.05$ \\
\hline Alstead, Ryan, Holdsworth ${ }^{10}$ & $150 \mathrm{mg}$ nocte & 15 & - & 7 & - & & 16 & - & 69 & - & $<0.005$ \\
\hline
\end{tabular}


in the treatment of gastric ulceration (GU). Abstract E26.5 Cimetidine 2774 Hepatogastroenterology 1980; suppl: 205

4 Machell RJ, Ciclitira PJ, Farthing MJG, Dick AP, Hunter JO. Cimetidine in the prevention of gastric ulcer relapse. Postgrad Med J 1979; 55: 393-5.

5 Birger Jensen K, Møllmann KM, Rahbek I, Rask Madsen J, Rune SJ, Wulff HR. Prophylactic effect of cimetidine in gastric ulcer patients. Scand J Gastroenterol 1979; 14: 175-6.

6 Hentschel E, Schütze, Weiss W, et al. Effect of cimetidine treatment in the prevention of gastric ulcer relapse: a one year double blind multicentre study. Gut 1983; 24: 853-6.

7 Barr GD, Kang JY, Canalese J, Piper DW. A twoyear prospective controlled study of maintenance cimetidine and gastric ulcer. Gastroenterology 1983; 85: $100-4$

8 Cockel R, Dawson J, Jain S. Ranitidine in the longterm treatment of gastric ulcers. In: Misiewicz JJ,
Wormsley KG, eds. The clinical use of ranitidine Oxford: Medicine Publishing Foundation, 1982: 232-8.

9 Hellier MD, Gent AE, Walker J, Britten D, Hutchison $\mathrm{C}$, Gough KR. Ranitidine in the treatment of gastric ulcers: healing and maintenance. Scand J Gastroenterol 1982; 17 suppl 78: 615.

10 Alstead EM, Ryan FP, Holdsworth CD, Ashton, Moore M. Ranitidine in the prevention of gastric and duodenal ulcer relapse. Gut 1983; 24: 418-20.

11 Record CO. Maintenance treatment with ranitidine in peptic ulceration. In: Tytgat GN, ed. Ranitidine, the selective new H2-receptor antagonist. Proceedings of Glaxo International Symposium, Amsterdam, 17-18 September 1982. Guildford: Theracom, 1982: 20-4.

12 Dronfield MW, Batchelor AJ, Larkworthy W, Langman MJS. Controlled trial of maintenance cimetidine treatment in healed duodenal ulcer: short and longterm effects. Gut 1979; 20: 526-30.

13 Baron JH, Alexander-Williams J, Bennett JR. Cimetidine and duodenal ulcer. Br Med J 1979; 1: 169-73. 
Annual research reviews. Substance $\mathbf{P}$ Vol 3 By Petr Skrabanek and David Powell. (Pp. 184; not illustrated; £30.25.) London: Eurospan Ltd, 1983.

Annual research reviews. Effects of hormones, drugs and chemicals on testicular function Vol 2 By A C Davies. (Pp. 215; not illustrated; £29.25.) London: Eurospan Ltd, 1983.

Annual research reviews. Hypothalamo-pituitary control of the ovary Vol 3 By J S M Hutchinson. (Pp. 213; not illustrated; £33.25.) London: Eurospan Ltd, 1983.

A clinical approach to progress in infectious diseases Edited by $\mathrm{W}$ Brunfitt and $\mathrm{J} M T$ Hamilton-Miller. (Pp. 163; illustrated; £12.50.) Oxford: Oxford University Press, 1983.

Royal Society of New Zealand Bulletin 20. Fibre in human and animal nutrition Edited by $G$ Wallace and L Bell. (Pp. 249; illustrated; \$25.00.) Wellington: Royal Society of New Zealand, 1983.

Acute pancreatitis. An interdisciplinary synopsis Edited by Hollender, Lehnert and Wanke. (Pp. 156; illustrated; £28.) London: Pitman Publishing Limited, 1984.

Actualities digestives medico chirurgicales Edited by J Mouiel. (Pp. 230; illustrated; price not stated.) Paris: Masson Editeur, 1984.

Colo-proctologue Edited by $\mathrm{J}$ Soullard and $\mathrm{J}$ F Contou. (Pp. 473; illustrated; price not stated.) Paris: Masson Editeur, 1984

Disorders of the oesophagus. Advances and controversies Edited by A Watson and L R Celestin. (Pp. 298; illustrated; £25.) London: Pitman, 1984.

Key references in gastroenterology. An annotated guide By McPhee, Richter, and Klingenstein. (Pp. 121; not illustrated; £9.95.) Edinburgh: Churchill Livingstone, 1983.

Home parenteral nutrition Edited by Ivan D A Johnston. (Pp. 83; illustrated; £6.95.) Lancaster: MTP Press Ltd, 1983.

Regulatory processes in clinical endocrinology Edited by Walter B Essman. (Pp. 171; illustrated; £23.25.) Lancaster: MTP Press Ltd, 1983.
Variceal bleeding Edited by D Westaby, B R D Macdougal, and Roger Williams. (Pp. 256; illustrated; £25.00.) London: Pitman Books Ltd, 1983.

Peptic ulcer disease. Advances in pathogenesis and treatment By G Bianchi Porro and K D Bardhan. (Pp. 171; illustrated; no price stated.) New York: Raven Press, 1982.

\section{News}

\section{Hepatobiliary and Pancreatic Surgery}

An advanced course in the above will be held at the Royal Postgraduate Medical School, London, on 4-8 November 1985. Details from the School Office (SSC), RPMS, Ducane Road, London W12 0HS.

\section{Colorectal Cancer Group}

The inaugural meeting will be held at the Royal Postgraduate Medical School at Hammersmith Hospital, on 29 November 1985. Information: Mr T. Cooke, Dept Surgery, Charing Cross Medical School, Fulham Palace Road, London W6 8RF, or Prof N. Wright, Dept Histopathology, RPMS, Ducane Road, London W12 0HS.

Hong Kong International Endoscopy Symposium There will be a two day symposium on 7 and 8 December 1985 in the Sheraton Hotel, Hong Kong. Further details can be obtained from Dr Joseph Leung, Department of Medicine, Prince of Wales Hospital, Shatin, Hong Kong.

\section{St Mark's Hospital: 150th anniversary}

The highlight of the 1985 celebrations for the 150th Anniversary at St Mark's Hospital was a three day scientific meeting held at the Barbican in London This was attended by 1295 delegates from 45 countries. An appeal to improve teaching, research, and patient care facilities at the hospital has been launched: further information is obtainable from the Appeal Committee, St Mark's Hospital, City Road, London EC1V 2PS.

\section{Correction}

Maintenance therapy: a two year comparison $\therefore$. Morgan, Pacsoo, McAdam (Gut 1985; 26: 599-602). In the Methods section on page 599 'bismuth subcitrate' should read 'bismuth subnitrate'. 